\title{
Yetişkinlerin Aile Değerlerinin Kişisel Bazı Değişkenlere Göre İncelenmesi
}

\author{
Prof. Dr. Arzu Özyürek ${ }^{1^{*}}$, Hüseyin Özpınar ${ }^{2}$, Arife Okcu ${ }^{3}$ \\ Büşra Seher Kabakuş ${ }^{4}$, Şerife Öksüzoğlu ${ }^{5}$, Serap Fikir ${ }^{6}$ \\ Şevki Akarsu' ${ }^{7}$ Mehmet Karaoğlu ${ }^{8}$, Muhammed Akif Yağımlı ${ }^{9}$ \\ Hülya Sahin ${ }^{10}$
}

Geliş tarihi: 18.06 .2019

Kabul tarihi: 11.08.2019

\section{Atuf bilgisi:}

IBAD Sosyal Bilimler Dergisi

Sayı: $5 \quad$ Sayfa: 121-133

Yıl: 2019 Dönem: Güz

This article was checked by Turnitin. Similarity Index 19\%

${ }^{1}$ Karabük Üniversitesi, Türkiye, https://orcid.org/0000-0002-3083-7202.

2Karabük Üniversitesi, Türkiye, huseyinozpinar@karabuk.edu.tr. ORCID ID https://orcid.org/0000-0001-6839-6003.

3Karabük Üniversitesi, Türkive, a.arife.okcu@hotmail.com. ORCID ID https://orcid.org/0000-0003-2460-7440.

4Karabük Üniversitesi, Türkive, sark gunesi@windowslive.com. ORCID ID https://orcid.org/0000-0001-6757-3565.

5Karabük Üniversitesi, Türkive, kehkesan_81@hotmail.com. ORCID ID https://orcid.org/0000-0002-4170-1087.

${ }^{6}$ Karabük Üniversitesi, Türkiye, serapfikir17@hotmail.com. ORCID ID https://orcid.org/0000-0002-0823-0914.

${ }^{7}$ Karabük Üniversitesi, Türkiye, sevkiakarsu@gmail.com. ORCID ID https://orcid.org/0000-0002-5747-4720.

${ }^{8}$ Karabük Üniversitesi, Türkiye, m.karaogluu@hotmail.com. ORCID ID https://orcid.org/0000-0002-2361-3243.

${ }^{9}$ Karabük Üniversitesi, Türkiye, makifyagimli@karabuk.edu.tr. ORCID ID https://orcid.org/0000-0002-4101-3831.

${ }^{10}$ Karabük Üniversitesi, Türkiye, s.hulya.sahin@gmail.com. ORCID ID https://orcid.org/0000-0001-9484-6602.

* Sorumlu yazar
$\ddot{O} \mathbf{Z}$

Bireyin bakım ve gelişiminin desteklenmesinde olduğu gibi değer eğitiminde de birinci derecede sorumlu kurum aile olarak görülmekte, bireyin değer kazanımı ailede başlamaktadır. Bireylerin görüşleri ise tutum ve davranışlarına yansımaktadır. $\mathrm{Bu}$ nedenle bu çalıșmada, yetișkinlerin aile değerlerine ilișkin görüșlerini bazı kişisel değişkenlere göre incelemek amaçlanmıştır. Betimsel tarama modelindeki çalışmada, çalışma grubu 18 yaş üzeri 201 kişiden oluşmuştur. Verilerin toplanmasında Aile Değerleri Ölçeği kullanılmıștır. Verilerin analizinde t-testi ve tek yönlü varyans analizi (ANOVA) kullanılmıştır. Sonuç olarak; aile değerlerinin cinsiyet, yaş, öğrenim düzeyi, meslek ve çocuk sayısına göre farklılaştı̆̆ belirlenmişti. Kadınların Karar Alma Süreçleri, Evliliğe Bakış, Kadının Rolleri, Duygusal Bağ ve Şiddet alt boyutlarının erkeklerin puanından; erkeklerin AnneÇocuk İlişkisi alt boyutu puanının kadınların puanından anlamlı düzeyde yüksek olduğu saptanmıştır. Yaşı 30 ve üzeri olanların Anne-Çocuk İlişkisi alt boyut puanı, 31 yaş ve üzeri yetişkinlere göre daha yüksek bulunmuştur. Lisans mezunu yetişkinlerin Şiddet alt boyut puanlarının ilköğretim mezunlarından, profesyonel meslek grubundaki yetişkinlerin Evliliğe Bakış ve Kadının Rolleri alt boyut puanlarının çalışmayan ve memur olanlardan daha yüksek olduğu belirlenmiştir. Ü̧̧ ve daha fazla çocuğu olan yetişkinlerin Cinselliğe Bakış alt boyut puanı tek çocuğu olanların puanına göre daha yüksek bulunmuştur. İki çocuğa sahip yetişkinlerin Anne-Cocuk İlișkisi puanı diğerlerinden düșük, hiç çocuğu olmayanların Akraba İlişkileri puanı ise bir çocuğu olanların puanına göre anlamlı düzeyde daha düşük bulunmuştur.

Anahtar Kelimeler: Aile Değerleri, Geleneksel Değerler, Evliliğe Bakış, Çocuğun Değeri. 


\title{
Analysis of Family Values of Adults According to Some Personal Variables
}

\author{
Prof. Dr. Arzu Özyürek ${ }^{*}, \quad$ Hüseyin Özpınar ${ }^{2}, \quad$ Arife Okcu ${ }^{3}$ \\ Büşra Seher Kabakuş ${ }^{4}$ ， Şerife Öksüzoğlu ${ }^{5}$ ， Serap Fikir ${ }^{6}$ \\ Şevki Akarsư ${ }^{7}$, Mehmet Karaoğlu ${ }^{8}$, Muhammed Akif Yağımlı \\ Hülya Şahin ${ }^{10}$
}

First received: 18.06 .2019

Accepted: 11.08.2019

\section{Citation:}

IBAD Journal of Social Sciences

Issue: 5

Pages: 121-133

Year: 2019 Session: Fall

This article was checked by Turnitin. Similarity Index 19\%

${ }^{1}$ Karabuk Universtiy, Turkey, a.ozyurek@karabuk.edu.tr,

https://orcid.org/0000-0002-3083-7202.

${ }^{2}$ Karabuk Universtiy, Turkey, husevinozpinar@karabuk.edu.tr. ORCID ID https://orcid.org/0000-0001-6839-6003.

${ }^{3}$ Karabuk Universtiy, Turkey,

a.arife.okcu@hotmail.com. ORCID ID

https://orcid.org/0000-0003-2460-7440.

${ }^{4}$ Karabuk Universtiy, Turkey,

sark gunesi@windowslive.com. ORCID ID

https://orcid.org/0000-0001-6757-3565.

Karabuk Universtiy, Turkey,

kehkesan_81@hotmail.com. ORCID ID

https://orcid.org/0000-0002-4170-1087.

${ }^{6}$ Karabük Üniversitesi, Türkive, serapfikir17@hotmail.com. ORCID ID https://orcid.org/0000-0002-0823-0914.

${ }^{7}$ Karabuk Universtiv, Turkey, sevkiakarsu@gmail.com. ORCID ID https://orcid.org/0000-0002-5747-4720.

8Karabuk Universtiv, Turkey, m.karaogluu@hotmail.com. ORCID ID https://orcid.org/0000-0002-2361-3243.

${ }^{9}$ Karabuk Universtiy, Turkey, makifyagimli@karabuk.edu.tr. ORCID ID https://orcid.org/0000-0002-4101-3831.

${ }^{10}$ Karabuk Universtiy, Turkey, s.hulya.sahin@gmail.com. ORCID ID https://orcid.org/0000-0001-9484-6602.

* Corresponding Author

\section{ABSTRACT}

Family is regarded as the foundation having the primary responsibility in both supporting individual's care and development, and values education. Individuals first start to acquire values from their families, and views of the individuals reflect on their behaviors and attitudes. Thus, in this study, it has been aimed to analyze views of the adults about family values according to some personal variables. The study was designed in accordance with descriptive survey model. Sample group of this study composed of 201 participants over the age of 18 . While gathering the data, there was used the Family Values Scale. The data was analyzed through t-test and One-way Analysis of Variance (ANOVA). As a result, it has been detected that gender, age, education, job and number of children have effect on family values. It has been found that scores of the females are significantly higher than males' in the sub-dimensions of Decision-making Process, Marital View, Roles of the Women, Emotional Bond, and Violence; and scores of the males are significantly higher than females' in the sub-dimension of Mother-Child Relationship. It has been discovered that scores of the Mother-Child Relationship sub-dimension is significantly higher in individuals at the age of 30 and below than individuals at the age of 31 and above. Also, it has been found that scores of the Violence sub-dimension is higher bachelor's degree than primary school graduates; and scores of Marital View and Roles of the Women sub-dimensions are higher for the adults having professional occupations than the adults being civil servant or having no job. For those having 3 or more children, it is found that scores of View of Sexuality sub-dimension are significantly much higher than those having only one child. While the scores of Mother-Child Relationship sub-dimension are significantly lower for those having 2 children, it has been found that scores of Relationship with Relatives sub-dimension are significantly lower for those having no child.

Keywords: Family Values, Traditional Values, Marital View, Value of the Child. 


\section{GİRIŞ}

Değer, kelime anlamı olarak bir şeyin önemini belirten, toplumsal kabul gören doğrular, inanılan, arzu edilen ve davranışlar, mevcut ile olmaması gerekenler arasındaki orta bir ölçüttür (Aydın ve Akyol Gürler, 2012). Bir nesne, varlık veya faaliyeti diğerlerinden daha üstün tutma, bir durumu diğerine tercih etme eğilimi anlamına gelmektedir (Aydın, 2017). Bireyin davranışlarına yön veren veya başkalarını yargılamaya etki eden değerler, topluma uyumu kolaylaştırırlar. Bu açıdan bakıldığında değerler, bireyin amaçlı ve bilinçli davranışlarının bir ölçütüdür (Ergene, 1999). Değer, Türk Dil Kurumu (2019) tarafindan da "Bir ulusun benimsediği kültürel, bilimsel ve ekonomik değerlerin tümünü oluşturan maddi-manevi olgu" şeklinde ele alınmaktadır.

Değerler doğuştan getirilmeyip sonradan kazanılan yargılardır. Bireyler arası sosyalleşme sürecini oluşturan değer kazanımı, eğitim yoluyla gerçekleşse de (Zajda, 2014) yalnızca okullardaki dersler aracılı̆̆ıyla sağlanmaz (Aydın, 2017). Bireyin değer kazanımında belki de en önemli etkiye sahip kurum, ailedir. Biçimsel olarak farklılıklar gösterse de aile; anne-baba-çocuklardan oluşan ve toplumdaki en küçük yapı taşıdır. Illk toplumlardan günümüze kadar ailenin var olduğu süreçte aile, kişilerin birbirine karşılıklı sadakat, sevgi ve saygısını içermektedir. Ailedeki düzen ve birlikte yaşama isteği hem biyolojik hem de sosyal bir kurum olarak nüfusun artması, biyolojik ve psikolojik doyum sağlama, milli kültürün aşılanması, sosyalleşme gibi rolleri üstlenir (Kızıler ve Canikli, 2015; Karadağ, 2015).

Türkiye Cumhuriyeti Anayasasının 42. maddesinde aile "Aile, Türk toplumunun temelidir ve eşler arasında eşitliğe dayanır. Devlet, ailenin huzur ve refahı ile özellikle ananın ve çocukların korunması ve aile planlamasının ögrretimi ile uygulanmasını sağlamak için gerekli tedbirleri alır, teşkilâtı kurar" (Türkiye Cumhuriyeti Anayasası, 1982). Şeklinde tanımlanmaktadır. Tanımdan da anlaşıldığı üzere kendine özgü değerleri bulunan aile, bireyin değer kazanımına önemli bir katkı sunmaktadır. Ailenin temellerinin atıldığı evlilik olgusu ise, toplumsal kabul gören yetişkin farklı iki cinsin bir araya gelerek kurdukları insan doğasında bulunan cinselliğin yasal yolla karşılanmasını ve insan kendi neslinin devamını sağlayan birliktelik olarak kabul edilmektedir (Giddens, 2000; Şeker, 2015).

Aile ve öğretmen, değer oluşturmada çocuk üzerinde etkin bir güce sahiptir. Yaşanarak aktarılan değerler başlangıçta alışkanlık olarak kazandırılabilir. Aile bireyleri ve öğretmenler, çocuğun bir değere bakışını ve kazanımını sadece anlatma yoluyla değil tutum ve davranışlarıyla da desteklerler. Çocuklar, içinde bulundukları toplumda doğru, yanlış, iye veya kötü davranışların neler olduğunu, bu davranışların nasıl hayata geçirildiğini öğrenmek ve bunları hayata geçirmek durumundadırlar (Aktepe ve Tahiroğlu, 2016). Çocuklar, tüm toplumlarda geleceğin yetişkinleri olarak görülür ve bu nedenle özenle yetiştirilir, eğitilir, eldeki imkânlar olabildiğince kullanılarak gereksinimleri karşılanmaya çalış1lır (Törüner ve Büyükgönenç, 2002). Çocuğun bu bağlamda kendini bir yere ait ve güvende hissettiği yer, doğduğu ve büyüdüğü ailesidir.

Biyolojik, ekonomik, eğitsel, dinsel ve boş zamanları değerlendirme işlevlerinde bulunan aile, toplumun devamında önemli bir rol üstlenmiştir. Dünyada ve Türkiye'de yaşanan değişimler, ailenin dinamikleri üzerinde etkili olmuştur. Ailenin kurulmasından sürdürülmesine ve çocuk sahibi olmaya kadar, bireylerin aileye bakışında farklılıklar oluştuğu söylenebilir. Aile bireysel özgürlüklerin kısıtlandığı bir ortam olarak görülmekte, boşanma kolaylaşmakta, tek ebeveynli aileler çoğalmakta, annelik ve çocuk sahibi olmak bireysel beklentiler ve kariyer arzusu sonucu ikinci planda kalabilmektedir. Haz ve tüketim ekseninde düşünülen yaşam tarzları neticesinde, kadın ve cinsiyet rollerine bakış açısı değişmektedir. Endüstrileşmenin etkisiyle modernlik adı altında ailenin geleneksel rollerinden uzaklaştığı görülmektedir. Bizzat değeri ifade eden ailenin, yaşanan sorunlar ve değişimler sonucundaki etkisi toplumun genelinde kendisini göstermektedir (Ekşi vd, 2010).

Değerler belli bazı özellikleri taşırlar. Örneğin; değerler değer yargılarının etkisindedirler, davranışları etkilemektedirler, belirli bir topluma ve belirli zamana aittirler, değerlerin kabul edilmesinde duygusallık önemlidir, değerler belirli bir hiyerarşik yapıya sahiptirler. Değerler ayrıca bireyin kişiliğinin ahlaki, dinsel, estetik, fiziksel veya sosyal değişik boyutlarını kapsamaktadırlar (Quisumbing ve de Leo, 2005). Modernleşme, şehirleşme ve sanayileşme aile yapısını değiştirmiş ve toplumda çekirdek aile düzeni hakim olmuştur. $\mathrm{Bu}$ durum, geleneksel değerleri tamamen ortadan kaldırmasa da kültürel değerlerin ailede temsil edilmesini önemli kılmıştır (Karadaş, 2012). Çeşitli kaynaklarda değerler saygı, sevgi, 
cesaret, sorumluluk, doğruluk, hoşgörü ve nezaket, adalet, onurlu olma gibi sıralanırken (Koç ve Akdoğan, 2018; Martorella, 2001) bilimsel, ekonomik, sosyal, estetik, mesleki, bireysel, toplumsal ve dini değerler, ahlaki veya ahlaki olmayan değerler, amaç veya araç değerler olarak da ele alınabilmektedir (Özer ve Aktaş, 2019). Aileye ilişkin değerlerin ise geleneksel aile değerleri, cinsellik, anne-çocuk ilişkisi, çocuğun değeri, karar alma süreçleri, evliliğe bakış, kadının rolleri, farklı yaklaşımlar, sosyo-ekonomik değer, akraba ilişkileri, duygusal bağ, sadakat ve aile içi şiddet olarak ele alındığı görülmektedir (Ekşi vd., 2010).

Aile değerlerine yönelik çalışmalar incelendiğinde, Ekşsi ve arkadaşları (2010) tarafından Türkiye'de Aile Değerleri araştırması, Abay ve Demir (2014) tarafından belli parametrelere göre kuşaklararası sosyal değişme, Ekşi ve arkadaşları (2015) tarafından Almanya'da ikamet eden Türklerin aile değerleri, televizyon reklamlarında aileye ilişkin değerlerin temsili (Karadaş, 2012), üniversite öğrencilerini aile değerlerine yönelik görüşleri (Özyürek, Çetin ve Erakman, 2016) konularında çalışmalara rastlanmıştır. Ailelerin sahip olduğu değerlerin incelenmesinin, günümüz toplumda değerlerle ilgili olumsuzlukların önlenmesinde yapılacak çalışmalara 1şık tutacağı düşünülmektedir. Halen değer eğitimden birinci derecede sorumlu kurumun aile olarak görüldüğü ve değer kazanımının ailede başladığından hareketle bu çalışmada, yetişkin bireylerin aile değerlerine ilişkin görüşlerini incelemek amaçlanmıştır. Çalışmada, "Cinsiyet, yaş, öğrenim durumu, meslek ve çocuk sayısına göre aile değerleri arasında fark var mıdır?" Sorularına cevap aranmıştır.

\section{YÖNTEM}

\subsection{Araştırmanın Modeli}

Betimsel tarama modelininin benimsendiği araştırmada, var olan durumu aydınlatmak (Sönmez ve Alacapınar, 2011), yetişkinlerin aile değerlerini mevcut haliyle ortaya koymak hedeflenmiştir.

\section{2. Çalışma Grubu}

Çalışma grubu, kendilerine ulaşılabilen ve çalışmaya katılmaya gönüllü 201 kişiden oluşmuştur. Çalışma grubundaki kişiler 18 yaş üzerinde olup 141'i kadın ve 60'1 erkektir. Tablo 1'de bazı kişisel bilgiler sunulmuştur.

Tablo 1. Çalışma Grubunun Kişisel Bazı Bilgilerinin Frekans ve Yüzdeleri

\begin{tabular}{|c|c|c|c|c|c|}
\hline Yaş & $\mathrm{n}$ & $\%$ & Gelir Durumu Algis1 & $\mathrm{n}$ & $\%$ \\
\hline 30 Yaş ve Altı & 56 & 27,9 & Düşük & 14 & 7,0 \\
\hline \multirow[t]{2}{*}{31 yaş ve üzeri } & 145 & 72,1 & Orta & 174 & 86,6 \\
\hline & & & Yüksek & 13 & 6,5 \\
\hline Öğrenim Durumu & & & \multicolumn{3}{|l|}{ Mesleği } \\
\hline İlköğretim & 22 & 10,9 & Çalışmiyor & 71 & 35,3 \\
\hline Lise & 37 & 18,4 & Profesyonel & 53 & 26,4 \\
\hline Önlisans & 76 & 37,8 & Memur & 39 & 19,4 \\
\hline Lisans & 39 & 19,4 & Serbest meslek & 38 & 18,9 \\
\hline Yüksek lisans & 27 & 13,4 & & & \\
\hline Evlilik Durumu & & & Çocuk Sayısı & & \\
\hline Bekar & 27 & 13,4 & Yok & 44 & 21,9 \\
\hline 1-10 Y1ll1k Evli & 10 & 5,0 & Tek çocuk & 41 & 20,4 \\
\hline \multirow[t]{2}{*}{ 11-20 Y1llık Evli } & 164 & 81,6 & İki çocuk & 80 & 39,8 \\
\hline & & & Üç ve daha fazla & 36 & 17,9 \\
\hline
\end{tabular}

Tablo 1'e göre, çalışma grubunun \%27,9'u 30 yaş ve daha küçük, $\% 72,1$ 'i 31 yaş ve üzeri yaşta; \%37,8'i ön lisans, \%18,4'lise ve \%19,4'ü lisans mezunudur; \%81,6's1 11-20 yıllık evli ve \%13,4'ü bekardır; \%86,6'sı gelirini düşük olarak belirtmiştir. Çalışma grubunun \%35,3'ü çalışmamakta, \%26,4'ü öğretmen veya doktor gibi profesyonel mesleğe sahip, \%19,4'ü memur ve \%18,9'u serbest meslekte çalışmaktadır; \%21,9'unun çocuğu yokken \%78,1'inin çocuğu vardır.

\subsection{Veri Toplama Araçları}

Katılımcıların aile değerlerinin belirlenmesinde, Aile Değerleri Ölçeği kullanılmıştır. Ekşi ve arkadaşlarının (2010) 18-52 yaş arası 313 kişiyle geliştirdiği, toplam 59 madde ve 13 alt boyuttan oluşan ölçek Kesinlikle Katılmıyorum (1 puan) Kesinlikle Katıliyorum (5 puan) ifadesine doğru derecelendirilmiş beşli likert tipindedir, 20 madde tersine puanlanmaktadır. Ölçek alt boyutları şu 
şekildedir: Geleneksel Aile Değerleri (GAD); (5 madde) ailenin geleneksel bakış açısıyla değerlendirildiğini, Cinselliğ $\boldsymbol{e}$ Bakış (CB); (5 madde) cinsellik ve cinsel konularda daha fazla serbestlikten yana olmayı, Anne-Çocuk Illişkisi (AÇ); (5 madde) çocuk bakımında annenin önemi ve anne-çocuk bağlantısının güçlü olması gerektiği, Çocuğun Değeri (ÇD); (5 madde) ailede çocuk yetiştirme konusuna daha fazla önem verilmesini, Karar Alma Süreçleri (KAS); (5 madde) ailede demokratik/katılımcı bir karar alma süreci olması gerektiğini, Evliliğe Bakıs (EB); (5 madde) evlilik ve evlilik kurumuna verilen önemi, Kadın Rolleri (KR); (5 madde) kadının aile içinde konvansiyonel bakış açısıyla değerlendirildiğini, Farklı Yaklaşımlar (FY); (5 madde) konvansiyonel olmayan değerlerin daha fazla benimsendiğini, Sosyo-Ekonomik Değer (EkD); (5 madde) ailenin genel olarak sosyal ve ekonomik bir yapı şeklinde algılanması eğilimini ve kariyer merkezli yaşantıların tercih edildiği, $\boldsymbol{A k r a b a}$ İlişkileri (Aki்); (5 madde) akraba ilişkilerine verilen önemi ve geniş aileye yönelik olumlu bakışı, Duygusal Băg (DuB); (4 madde) aileye yönelik duygusal bağlılı̆̆ın artması, Sadakat (SAD); (3 madde) eşler arasındaki sadakate önem verilmesi ve Şiddet (ŞiD); (2 madde) ailenin saadeti için uygulanan şiddetin meşru görülmesi şeklinde yorumlanmaktadır. Yüksek puan her alt boyut için olumlu olarak puanlanmaktadır. Ölçek Cronbach Alpha güvenirlik katsayısı tüm ölçek için 0,89, alt boyutların için sırasıyla $.95, .95, .95, .94, .93, .92, .93, .92, .92, .92, .90, .89$ ve .99 olarak belirlenmiştir (Ekşi vd., 2010).

\subsection{Verilerin Toplanması ve Analizi}

Veriler, online katılımla toplanmıştır. Ölçek maddeleri ve değerlendirme ölçütü bilgisayar ortamına girilmiş, katılıma gönüllü olanların bilgisayar ortamında form maddelerini işaretleyerek kaydetmeleri istenmiştir. Kayıtlı bilgiler daha sonra istatistik programında değerlendirilmiştir. Veriler, normallik dağılımlarından yola çıkılarak t-testi ve tek yönlü varyans analizi (ANOVA) ile analiz edilmiştir.

\section{BULGULAR}

Tablo 2'de, cinsiyet ve Tablo 3'te yaş değişkenine göre katılımcıların Aile Değerleri Ölçeği analiz sonuçları görülmektedir.

Tablo 2. Cinsiyete Göre Aile Değerleri Ölçeği Puanları t-Testi Sonuçları

\begin{tabular}{|c|c|c|c|c|c|c|}
\hline Aile Değerleri Ölçeği & Cinsiyet & $\mathrm{n}$ & Ortalama & Standart Sapma & $\mathrm{t}$ & $\mathrm{p}$ \\
\hline \multirow[t]{2}{*}{ Geleneksel Aile Değerleri } & Kadın & 141 & 9,87 & 3,10 & 1,886 & 0,061 \\
\hline & Erkek & 60 & 9,00 & 2,82 & & \\
\hline \multirow[t]{2}{*}{ Cinselliğe Bakış } & Kadın & 141 & 19,63 & 2,03 & 0,066 & 0,948 \\
\hline & Erkek & 60 & 19,61 & 2,37 & & \\
\hline \multirow[t]{2}{*}{ Anne-Çocuk İlişkisi } & Kadın & 141 & 14,75 & 2,29 & $-4,496$ & $0,000 *$ \\
\hline & Erkek & 60 & 16,45 & 2,78 & & \\
\hline \multirow[t]{2}{*}{ Çocuğun Değeri } & Kadın & 141 & 11,47 & 2,75 & 0,143 & 0,886 \\
\hline & Erkek & 60 & 11,41 & 2,35 & & \\
\hline \multirow[t]{2}{*}{ Karar Alma Süreçleri } & Kadın & 141 & 12,19 & 2,55 & 2,308 & $0,022 *$ \\
\hline & Erkek & 60 & 11,35 & 1,92 & & \\
\hline \multirow[t]{2}{*}{ Evliliğe Bakış } & Kadın & 141 & 17,41 & 2,97 & 3,583 & $0,000^{*}$ \\
\hline & Erkek & 60 & 15,80 & 2,77 & & \\
\hline \multirow[t]{2}{*}{ Kadının Rolleri } & Kadın & 141 & 15,28 & 3,27 & 5,087 & $0,000^{*}$ \\
\hline & Erkek & 60 & 12,88 & 2,47 & & \\
\hline \multirow[t]{2}{*}{ Farklı Yaklaşımlar } & Kadın & 141 & 18,67 & 2,39 & 0,889 & 0,375 \\
\hline & Erkek & 60 & 18,31 & 3,05 & & \\
\hline \multirow[t]{2}{*}{ Sosyo-Ekonomik Değer } & Kadın & 141 & 13,52 & 2,86 & 1,479 & 0,141 \\
\hline & Erkek & 60 & 12,88 & 2,68 & & \\
\hline \multirow[t]{2}{*}{ Akraba İlişkileri } & Kadın & 141 & 15,04 & 2,18 & 0,240 & 0,811 \\
\hline & Erkek & 60 & 14,96 & 2,37 & & \\
\hline \multirow[t]{2}{*}{ Duygusal Bağ } & Kadın & 141 & 12,40 & 1,69 & 3,174 & $0,002 *$ \\
\hline & Erkek & 60 & 11,51 & 2,06 & & \\
\hline \multirow{2}{*}{ Sadakat } & Kadın & 141 & 11,95 & 2,14 & $-0,542$ & 0,588 \\
\hline & Erkek & 60 & 12,13 & 2,01 & & \\
\hline \multirow[t]{2}{*}{ Şiddet } & Kadın & 141 & 9,23 & 1,19 & 3,290 & $0,001 *$ \\
\hline & Erkek & 60 & 8,55 & 1,66 & & \\
\hline
\end{tabular}

Tablo 2'ye göre cinsiyet değişkeni ile Aile Değerleri Ölçeği AÇ, KAS, EB, KR, DuB ve ŞíD alt boyut puanları arasında anlamlı bir fark vardır $(\mathrm{p}<0,05)$. KAS, EB, KR, DuB ve ŞiD alt boyutlarında erkeklerin 
puanı kadınların puanından; AÇ alt boyutunda ise kadınların puanı erkeklerin puanından anlamlı düzeyde düşüktür.

Tablo 3. Yaşa Göre Aile Değerleri Ölçeği Puanları t-Testi Sonuçları

\begin{tabular}{|c|c|c|c|c|c|c|}
\hline Aile Değerleri Ölçeği & Yaş & $\mathrm{n}$ & Ortalama & Standart Sapma & $\mathrm{t}$ & $\mathrm{p}$ \\
\hline \multirow{2}{*}{ Geleneksel Aile Değerleri } & 30 yaş ve altı & 56 & 9,58 & 3,26 & \multirow{2}{*}{$-0,080$} & \multirow{2}{*}{0,937} \\
\hline & 31 yaş ve üstü & 145 & 9,62 & 2,96 & & \\
\hline \multirow{2}{*}{ Cinselliğe Bakış } & 30 yaş ve altı & 56 & 19,58 & 2,61 & \multirow{2}{*}{$-0,175$} & \multirow{2}{*}{0,861} \\
\hline & 31 yaş ve üstü & 145 & 19,64 & 1,93 & & \\
\hline \multirow{2}{*}{ Anne-Çocuk İliş̧kisi } & 30 yaş ve altı & 56 & 16,00 & 2,28 & \multirow{2}{*}{2,581} & \multirow{2}{*}{$0,011^{*}$} \\
\hline & 31 yaş ve üstü & 145 & 14,97 & 2,61 & & \\
\hline \multirow{2}{*}{ Çocuğun Değeri } & 30 yaş ve altı & 56 & 11,37 & 2,33 & \multirow{2}{*}{$-0,275$} & \multirow{2}{*}{0,783} \\
\hline & 31 yaş ve üstü & 145 & 11,48 & 2,75 & & \\
\hline \multirow{2}{*}{ Karar Alma Süreçleri } & 30 yaş ve altı & 56 & 11,89 & 2,26 & \multirow{2}{*}{$-0,191$} & \multirow{2}{*}{0,849} \\
\hline & 31 yaş ve üstü & 145 & 11,96 & 2,47 & & \\
\hline \multirow{2}{*}{ Evliliğe Bakış } & 30 yaş ve altı & 56 & 17,48 & 3,09 & \multirow{2}{*}{1,626} & \multirow{2}{*}{0,106} \\
\hline & 31 yaş ve üstü & 145 & 16,71 & 2,94 & & \\
\hline \multirow{2}{*}{ Kadının Rolleri } & 30 yaş ve altı & 56 & 14,50 & 3,44 & \multirow{2}{*}{$-0,182$} & \multirow{2}{*}{0,856} \\
\hline & 31 yaş ve üstü & 145 & 14,59 & 3,17 & & \\
\hline \multirow{2}{*}{ Farklı Yaklaşımlar } & 30 yaş ve altı & 56 & 18,33 & 2,91 & \multirow{2}{*}{$-0,770$} & \multirow{2}{*}{0,442} \\
\hline & 31 yaş ve üstü & 145 & 18,65 & 2,47 & & \\
\hline \multirow{2}{*}{ Sosyo-Ekonomik Değer } & 30 yaş ve altı & 56 & 13,14 & 2,78 & \multirow{2}{*}{$-0,594$} & \multirow{2}{*}{0,553} \\
\hline & 31 yaş ve üstü & 145 & 13,40 & 2,84 & & \\
\hline \multirow{2}{*}{ Akraba İlişkileri } & 30 yaş ve altı & 56 & 14,82 & 2,32 & \multirow{2}{*}{$-0,800$} & \multirow{2}{*}{0,425} \\
\hline & 31 yaş ve üstü & 145 & 15,10 & 2,20 & & \\
\hline \multirow{2}{*}{ Duygusal Bağ } & 30 yaş ve altı & 56 & 11,78 & 1,77 & \multirow{2}{*}{$-1,687$} & 0093 \\
\hline & 31 yaş ve üstü & 145 & 12,27 & 1,87 & & 0,093 \\
\hline Sadakat & 30 yaş ve altı & 56 & 11,55 & 2,76 & -1928 & 0.055 \\
\hline sauakat & 31 yaş ve üstü & 145 & 12,18 & 1,75 & $-1,920$ & 0,035 \\
\hline Siddet & 30 yaş ve altı & 56 & 8,75 & 1,78 & -1794 & \\
\hline Şवüt & 31 yaş ve üstü & 145 & 9,13 & 1,18 & $-1, / 94$ & $0,0 / 4$ \\
\hline
\end{tabular}

$* \mathrm{p}<0,05$

Tablo 3 incelendiğinde, yaş değişken ile Aile Değerleri Ölçeği AÇ alt boyut puanları arasındaki fark anlamlıdır ( $\mathrm{p}<0,05)$. AÇ alt boyut puanı 30 yaş ve daha küçük yaştaki yetişkinlerde (Ort.: 16,00), 31 yaş ve üzeri yetişkinlere göre anlamlı ölçüde daha yüksektir (Ort.: 14,97).

Tablo 4'te, öğrenim durumu, Tablo 5'te meslek ve Tablo 6'da çocuk sayısı değişkenine göre katılımcıların Aile Değerleri Ölçeği analiz sonuçları sunulmuştur.

Tablo 4. Öğrenim Durumuna Göre Aile Değerleri Ölçeği Puanları ANOVA Sonuçları

\begin{tabular}{|c|c|c|c|c|c|c|}
\hline Aile Değerleri Ölçeği & Öğrenim & $\mathrm{n}$ & Ortalama & Standart Sapma & $\mathrm{F}$ & $\mathrm{p}$ \\
\hline \multirow[t]{5}{*}{ Geleneksel Aile Değerleri } & İlköğretim & 22 & 9,81 & 2,26 & 1,663 & 0,160 \\
\hline & Lise & 37 & 9,40 & 2,54 & & \\
\hline & Ön lisans & 76 & 10,18 & 3,60 & & \\
\hline & Lisans & 39 & 8,69 & 2,70 & & \\
\hline & Lisans üstü & 27 & 9,48 & 2,76 & & \\
\hline \multirow[t]{5}{*}{ Cinselliğe Bakış } & İlköğretim & 22 & 20,20 & 2,22 & 2,139 & 0,077 \\
\hline & Lise & 37 & 19,56 & 2,00 & & \\
\hline & Ön lisans & 76 & 19,17 & 2,50 & & \\
\hline & Lisans & 39 & 20,20 & 1,37 & & \\
\hline & Lisans üstü & 27 & 19,66 & 1,79 & & \\
\hline \multirow[t]{5}{*}{ Anne-Çocuk İlişkisi } & İlköğretim & 22 & 15,40 & 2,93 & 1,530 & 0,195 \\
\hline & Lise & 37 & 14,37 & 2,34 & & \\
\hline & Ön lisans & 76 & 15,63 & 2,65 & & \\
\hline & Lisans & 39 & 15,30 & 2,24 & & \\
\hline & Lisans üstü & 27 & 15,22 & 2,59 & & \\
\hline \multirow{2}{*}{ Çocuğun Değeri } & İlköğretim & 22 & 12,09 & 3,70 & 1,149 & 0,335 \\
\hline & Lise & 37 & 11,56 & 2,58 & & \\
\hline
\end{tabular}




\begin{tabular}{|c|c|c|c|c|c|c|}
\hline & Ön lisans & 76 & 11,47 & 2,28 & & \\
\hline & Lisans & 39 & 10,74 & 2,65 & & \\
\hline & Lisans üstü & 27 & 11,77 & 2,57 & & \\
\hline \multirow[t]{5}{*}{ Karar Alma Süreçleri } & İlköğretim & 22 & 11,54 & 2,90 & 0,692 & 0,598 \\
\hline & Lise & 37 & 11,78 & 2,21 & & \\
\hline & Ön lisans & 76 & 11,96 & 2,34 & & \\
\hline & Lisans & 39 & 11,84 & 2,25 & & \\
\hline & Lisans üstü & 27 & 12,59 & 2,69 & & \\
\hline \multirow[t]{5}{*}{ Evliliğe Bakış } & İlköğretim & 22 & 15,45 & 3,69 & 2,048 & 0,089 \\
\hline & Lise & 37 & 16,62 & 2,32 & & \\
\hline & Ön lisans & 76 & 17,39 & 2,99 & & \\
\hline & Lisans & 39 & 17,87 & 3,16 & & \\
\hline & Lisans üstü & 27 & 17,33 & 2,73 & & \\
\hline \multirow[t]{5}{*}{ Kadının Rolleri } & İlköğretim & 22 & 13,50 & 3,47 & 1,580 & 0,181 \\
\hline & Lise & 37 & 13,97 & 2,86 & & \\
\hline & Ön lisans & 76 & 14,86 & 3,69 & & \\
\hline & Lisans & 39 & 14,53 & 2,74 & & \\
\hline & Lisans üstü & 27 & 15,44 & 2,63 & & \\
\hline \multirow[t]{5}{*}{ Farklı Yaklaşımlar } & İlköğretim & 22 & 18,31 & 2,07 & 2,006 & 0,095 \\
\hline & Lise & 37 & 18,43 & 2,36 & & \\
\hline & Ön lisans & 76 & 18,09 & 3,05 & & \\
\hline & Lisans & 39 & 19,15 & 2,27 & & \\
\hline & Lisans üstü & 27 & 19,44 & 2,10 & & \\
\hline \multirow[t]{5}{*}{ Sosyo-Ekonomik Değer } & İlköğretim & 22 & 13,54 & 2,32 & 1,150 & 0,334 \\
\hline & Lise & 37 & 13,21 & 2,61 & & \\
\hline & Ön lisans & 76 & 13,51 & 2,99 & & \\
\hline & Lisans & 39 & 12,56 & 2,79 & & \\
\hline & Lisans üstü & 27 & 13,92 & 2,94 & & \\
\hline \multirow[t]{5}{*}{ Akraba İlişkileri } & İlköğretim & 22 & 15,09 & 2,02 & 1,008 & 0,405 \\
\hline & Lise & 37 & 14,91 & 2,37 & & \\
\hline & Ön lisans & 76 & 15,36 & 2,35 & & \\
\hline & Lisans & 39 & 14,82 & 2,08 & & \\
\hline & Lisans üstü & 27 & 14,44 & 2,06 & & \\
\hline \multirow[t]{5}{*}{ Duygusal Băg } & İlköğretim & 22 & 12,59 & 2,17 & 2,084 & 0,084 \\
\hline & Lise & 37 & 12,13 & 1,84 & & \\
\hline & Ön lisans & 76 & 11,78 & 1,75 & & \\
\hline & Lisans & 39 & 12,71 & 1,65 & & \\
\hline & Lisans üstü & 27 & 11,92 & 1,99 & & \\
\hline \multirow[t]{5}{*}{ Sadakat } & İlköğretim & 22 & 11,68 & 2,47 & 1,058 & 0,379 \\
\hline & Lise & 37 & 11,86 & 2,09 & & \\
\hline & Ön lisans & 76 & 11,89 & 2,10 & & \\
\hline & Lisans & 39 & 12,05 & 1,77 & & \\
\hline & Lisans üstü & 27 & 12,74 & 2,19 & & \\
\hline \multirow[t]{5}{*}{ Şiddet } & İlköğretim & 22 & 8,27 & 1,60 & 3,602 & $0,007 *$ \\
\hline & Lise & 37 & 9,35 & 0,85 & & \\
\hline & Ön lisans & 76 & 8,82 & 1,54 & & \\
\hline & Lisans & 39 & 9,41 & 0,78 & & \\
\hline & Lisans üstü & 27 & 9,22 & 1,67 & Fark: & $1-4$ \\
\hline
\end{tabular}

Tablo 4'e göre, katılımcıların öğrenim durumu ile Aile Değerleri Ölçeği şiD alt boyut puanları arasındaki fark anlamlıdır $(\mathrm{p}<0,05)$. Scheffe Testi ile incelendiğinde, farkın kaynağının ilköğretim mezunu ve lisans mezunları arasında olduğu görülmüştür. İlköğretim mezun yetişkinlerin Şi̇ alt boyut ortalama puanı (Ort.: 8,27), lisans mezunlarının aynı puanından (Ort.: 9,41) anlamlı düzeyde düşüktür. 
Tablo 5. Mesleğe Göre Aile Değerleri Ölçeği Puanları ANOVA Sonuçları

\begin{tabular}{|c|c|c|c|c|c|c|}
\hline Aile Değerleri Ölçeği & Meslek & $\mathrm{n}$ & Ortalama & Standart Sapma & $\mathrm{F}$ & $\mathrm{p}$ \\
\hline \multirow{4}{*}{ Geleneksel Aile Değerleri } & Çalıșmıyor & 71 & 9,50 & 2,71 & 1,185 & 0,316 \\
\hline & Profesyonel meslek & 53 & 10,26 & 3,28 & & \\
\hline & Memur & 39 & 9,17 & 2,77 & & \\
\hline & Serbest meslek & 38 & 9,36 & 3,35 & & \\
\hline \multirow[t]{4}{*}{ Cinselliğe Bakış } & Çalışmıyor & 71 & 19,97 & 2,10 & 1,335 & 0,264 \\
\hline & Profesyonel meslek & 53 & 19,20 & 2,03 & & \\
\hline & Memur & 39 & 19,53 & 2,40 & & \\
\hline & Serbest meslek & 38 & 19,68 & 2,01 & & \\
\hline \multirow[t]{4}{*}{ Anne-Çocuk İlişkisi } & Çalışmıyor & 71 & 14,80 & 2,36 & 1,543 & 0,205 \\
\hline & Profesyonel meslek & 53 & 15,45 & 2,26 & & \\
\hline & Memur & 39 & 15,84 & 3,17 & & \\
\hline & Serbest meslek & 38 & 15,23 & 2,57 & & \\
\hline \multirow[t]{4}{*}{ Çocuğun Değeri } & Çalışmıyor & 71 & 11,42 & 2,87 & 1,061 & 0,367 \\
\hline & Profesyonel meslek & 53 & 11,88 & 2,72 & & \\
\hline & Memur & 39 & 10,89 & 2,01 & & \\
\hline & Serbest meslek & 38 & 11,50 & 2,60 & & \\
\hline \multirow[t]{4}{*}{ Karar Alma Süreçleri } & Çalışmıyor & 71 & 11,85 & 2,53 & 1,127 & 0,339 \\
\hline & Profesyonel meslek & 53 & 12,41 & 2,61 & & \\
\hline & Memur & 39 & 11,51 & 2,29 & & \\
\hline & Serbest meslek & 38 & 11,89 & 1,92 & & \\
\hline \multirow[t]{4}{*}{ Evliliğe Bakış } & Çalışmıyor & 71 & 16,43 & 2,87 & 7,461 & $0,000^{*}$ \\
\hline & Profesyonel meslek & 53 & 18,39 & 3,03 & & \\
\hline & Memur & 39 & 15,76 & 2,47 & & \\
\hline & Serbest meslek & 38 & 17,00 & 2,97 & Fark & 1,3 \\
\hline \multirow[t]{4}{*}{ Kadının Rolleri } & Çalışmıyor & 71 & 14,11 & 2,86 & 3,658 & $0,013 *$ \\
\hline & Profesyonel meslek & 53 & 15,77 & 3,59 & & \\
\hline & Memur & 39 & 13,87 & 3,27 & & \\
\hline & Serbest meslek & 38 & 14,44 & 3,03 & Fark & 1,3 \\
\hline \multirow[t]{4}{*}{ Farklı Yaklaşımlar } & Çalışmıyor & 71 & 18,53 & 2,06 & 0,182 & 0,908 \\
\hline & Profesyonel meslek & 53 & 18,66 & 2,68 & & \\
\hline & Memur & 39 & 18,33 & 3,23 & & \\
\hline & Serbest meslek & 38 & 18,73 & 2,76 & & \\
\hline \multirow[t]{4}{*}{ Sosyo-Ekonomik Değer } & Çalışmıyor & 71 & 13,35 & 2,63 & 2,191 & 0,090 \\
\hline & Profesyonel meslek & 53 & 14,05 & 3,18 & & \\
\hline & Memur & 39 & 12,61 & 2,676 & & \\
\hline & Serbest meslek & 38 & 10,02 & 2,63 & & \\
\hline \multirow[t]{4}{*}{ Akraba İlişkileri } & Çalışmıyor & 71 & 15,09 & 2,12 & 0,417 & 0,741 \\
\hline & Profesyonel meslek & 53 & 15,11 & 2,11 & & \\
\hline & Memur & 39 & 15,12 & 1,82 & & \\
\hline & Serbest meslek & 38 & 14,65 & 2,92 & & \\
\hline \multirow[t]{4}{*}{ Duygusal Bağ } & Çalışmıyor & 71 & 12,29 & 1,79 & 1,001 & 0,394 \\
\hline & Profesyonel meslek & 53 & 12,01 & 1,77 & & \\
\hline & Memur & 39 & 11,76 & 1,82 & & \\
\hline & Serbest meslek & 38 & 12,39 & 2,09 & & \\
\hline \multirow[t]{4}{*}{ Sadakat } & Çalışmıyor & 71 & 11,95 & 2,23 & 0,282 & 0,838 \\
\hline & Profesyonel meslek & 53 & 12,22 & 2,33 & & \\
\hline & Memur & 39 & 11,84 & 1,58 & & \\
\hline & Serbest meslek & 38 & 11,97 & 2,00 & & \\
\hline \multirow[t]{4}{*}{ Şiddet } & Çalışmıyor & 71 & 8,95 & 1,34 & 1,321 & 0,269 \\
\hline & Profesyonel meslek & 53 & 9,24 & 1,59 & & \\
\hline & Memur & 39 & 9,71 & 1,46 & & \\
\hline & Serbest meslek & 38 & 9,18 & 0,95 & & \\
\hline
\end{tabular}

Tablo 5'e göre, katılımcıların öğrenim durumu ile Aile Değerleri Ölçeği EB ve KR alt boyut puanları arasındaki fark anlamlıdır $(\mathrm{p}<0,05)$. Avukat ve doktor gibi profesyonel bir mesleğe sahip olan yetişkinlerin Evliliğe Bakış ve Kadının rolleri alt boyut ortalama puanı (Ort.: 18, 39, Ort.: 15,77), çalışmayan (Ort.: 16,43 ort.:14,11 ) ve memur olanların puanına göre (Ort.:15,76, Ort.: 13,87) anlamlı düzeyde daha yüksektir. 
Tablo 6. Çocuk Sayısına Göre Aile Değerleri Ölçeği Puanları ANOVA Sonuçları

\begin{tabular}{|c|c|c|c|c|c|c|}
\hline Aile Değerleri Ölçeği & Çocuk Sayısı & $\mathrm{n}$ & Ortalama & Standart Sapma & $\mathrm{F}$ & $\mathrm{p}$ \\
\hline \multirow[t]{4}{*}{ Geleneksel Aile Değerleri } & Yok & 44 & 10,04 & 3.84 & 0,496 & 0,685 \\
\hline & Tek çocuk & 41 & 9,70 & 3,22 & & \\
\hline & İki çocuk & 80 & 9,48 & 2,81 & & \\
\hline & Üç ve daha fazla & 36 & 9,27 & 2,11 & & \\
\hline \multirow[t]{4}{*}{ Cinselliğe Bakış } & Yok & 44 & 19,43 & 2,44 & 2,922 & $0,035^{*}$ \\
\hline & Tek çocuk & 41 & 19,04 & 2,65 & & \\
\hline & İki çocuk & 80 & 19,63 & 1,93 & & \\
\hline & Üç ve daha fazla & 36 & 20,47 & 1,05 & \multicolumn{2}{|c|}{ Fark: 2-4 } \\
\hline \multirow[t]{4}{*}{ Anne-Çocuk İlişkisi } & Yok & 44 & 15,90 & 2,19 & \multirow[t]{3}{*}{2,976} & \multirow[t]{3}{*}{$0,033^{*}$} \\
\hline & Tek çocuk & 41 & 15,31 & 2,81 & & \\
\hline & İki çocuk & 80 & 14,65 & 2,54 & & \\
\hline & Üç ve daha fazla & 36 & 15,75 & 2,53 & \multicolumn{2}{|c|}{ Fark: $3-1,2,4$} \\
\hline \multirow[t]{4}{*}{ Çocuğun Değeri } & Yok & 44 & 11,56 & 2,50 & \multirow[t]{4}{*}{0,150} & \multirow[t]{4}{*}{0,930} \\
\hline & Tek çocuk & 41 & 11,60 & 2,43 & & \\
\hline & İki çocuk & 80 & 11,31 & 2,43 & & \\
\hline & Üç ve daha fazla & 36 & 11,47 & 2,73 & & \\
\hline \multirow[t]{4}{*}{ Karar Alma Süreçleri } & Yok & 44 & 11,88 & 2,15 & \multirow[t]{4}{*}{0,607} & \multirow[t]{4}{*}{0,611} \\
\hline & Tek çocuk & 41 & 12,29 & 2,59 & & \\
\hline & İki çocuk & 80 & 11,97 & 2,47 & & \\
\hline & Üç ve daha fazla & 36 & 11,55 & 2,38 & & \\
\hline \multirow[t]{4}{*}{ Evliliğe Bakış } & Yok & 44 & 17,22 & 3,17 & \multirow[t]{4}{*}{1,132} & \multirow[t]{4}{*}{0,337} \\
\hline & Tek çocuk & 41 & 17,48 & 3,22 & & \\
\hline & İki çocuk & 80 & 16,72 & 2,72 & & \\
\hline & Üç ve daha fazla & 36 & 16,38 & 3,09 & & \\
\hline \multirow[t]{4}{*}{ Kadının Rolleri } & Yok & 44 & 15,68 & 3,58 & \multirow[t]{4}{*}{2,441} & \multirow[t]{4}{*}{0,066} \\
\hline & Tek çocuk & 41 & 14,09 & 3,52 & & \\
\hline & İki çocuk & 80 & 14,43 & 2,92 & & \\
\hline & Üç ve daha fazla & 36 & 14,02 & 2,97 & & \\
\hline Farklı Yaklaşımlar & Yok & 44 & 18,11 & 2,45 & 0,614 & 0,607 \\
\hline & Tek çocuk & 41 & 18,56 & 3,41 & & \\
\hline & İki çocuk & 80 & 18,73 & 2,37 & & \\
\hline & Üç ve daha fazla & 36 & 18,75 & 2,23 & & \\
\hline Sosyo-Ekonomik Değer & Yok & 44 & 13,43 & 2,98 & 0,110 & 0,954 \\
\hline & Tek çocuk & 41 & 13,43 & 2,58 & & \\
\hline & İki çocuk & 80 & 13,32 & 3,00 & & \\
\hline & Üç ve daha fazla & 36 & 13,11 & 2,54 & & \\
\hline Akraba İlişkileri & Yok & 44 & 14,43 & 2,32 & 3,827 & $0,011 *$ \\
\hline & Tek çocuk & 41 & 15,87 & 2,77 & & \\
\hline & İki çocuk & 80 & 15,13 & 1,86 & & \\
\hline & Üç ve daha fazla & 36 & 14,52 & 1,93 & & \\
\hline Duygusal Bağ & Yok & 44 & 11,61 & 1,79 & 2,232 & 0,086 \\
\hline & Tek çocuk & 41 & 12,24 & 1,68 & & \\
\hline & İki çocuk & 80 & 12,13 & 1,94 & & \\
\hline & Üç ve daha fazla & 36 & 12,66 & 1,82 & & \\
\hline Sadakat & Yok & 44 & 11,63 & 1,97 & 1,283 & 0,281 \\
\hline & Tek çocuk & 41 & 11,87 & 2,61 & & \\
\hline & İki çocuk & 80 & 12,35 & 1,92 & & \\
\hline & Üç ve daha fazla & 36 & 11,86 & 1,91 & & \\
\hline Şiddet & Yok & 44 & 9,09 & 1,49 & 1,779 & 0,153 \\
\hline & Tek çocuk & 41 & 8,60 & 1,82 & & \\
\hline & İki çocuk & 80 & 9,21 & 1,16 & & \\
\hline & Üç ve daha fazla & 36 & 9,02 & 0,99 & & \\
\hline
\end{tabular}

Tablo 6'ya göre, katılımcıların çocuk sayısı ile Aile Değerleri Ölçeği CB, AÇ ve Aİ alt boyut puanları arasında anlamlı fark vardır $(\mathrm{p}<0,05)$. Üç ve daha fazla çocuğu olan yetişkinlerin $\mathrm{CB}$ alt boyut puanı (Ort.: 20,47) tek çocuğu olanların puanına göre (Ort.: 19,04) anlamlı düzeyde daha yüksektir. İki çocuğa sahip yetişkinlerin AÇ alt boyut puanı (Ort.:14,65) çocuğu olmayan veya ikiden fazla çocuğu olanlara 
göre daha düşük; hiç çocuğu olmayanların Aİ alt boyut puanı (Ort.: 14,43) bir çocuğu olanların puanına göre (Ort.: 15,87) anlamlı düzeyde daha düşüktür.

\section{TARTIŞMA ve SONUÇ}

Yetişkinlerin aile değerlerinin incelendiği bu çalışmada, kadınların erkeklere göre daha fazla aile içinde karar alma sürecinin demokratik olması ve kadının aile içindeki rolünün anlaşmaya dayalı olması gerektiği görüşünde oldukları, aileye duygusal bağl1lıklarının fazla olduğu ve ailenin saadeti için şiddeti meşru görme oranlarının erkeklerden yüksek olduğu belirlenmiştir. Elde edilen bu bulgular, toplumda geleneksel ataerkil ile yapısının halen baskın olduğunu düşündürmektedir. Oysa aile içinde hem kadının hem de erkeğin önemli bir yeri vardır ve yapılan pek çok çalışma, annelerin olduğu kadar babaların da aile içinde, özellikle çocukların gelişimindeki önemine vurgu yapmaktadır (Akt.: Dermott, 2014). Bunun yanında günümüzde, şiddet toplumların önemli bir sorunu olarak görülmektedir. Erkeğin kadına ve çocuğa karşı uyguladığı şiddeti tanımlayan aile içi şiddet ise, en yaygın olan şiddet türüdür. Şiddetin asıl kaynağının toplumsal cinsiyet eşitsizliği ve geleneksel/ataerkil aile yapısından kaynaklandığı söylenebilir (Kızmaz, 2006). Türkiye'de de aile içi şiddet yaygın olarak görülmekte, yaşanan sorunlar mahrem kabul edilmekte, kadınlar ise bu duruma bir çıkış yolu bulamamaktadırlar. Kadınların, erkeklere göre aile içi şiddeti meşru görme oranının fazla olması, kadınların bu durumu daha çok kanıksamış olmaları şeklinde yorumlanabilir.

Çalışmada, erkeklerin kadınlardan daha fazla çocuk bakımı hususunda annenin ön planda olması ve anne-çocuk bağlantısının güçlü olması gerektiği görüşünde oldukları belirlenmiştir. Anne-babanın aile içindeki rolü bazen benzer bazen farklı ve birbirini tamamlayıcı olabilmektedir. Sosyal Rol Kuramına göre, bireyler kişisel bazı özellikler yanında çevresel özelliklerin etkisiyle farklı davranış özellikleri kazandıklarından bu durum değişiklik gösterebilmektedir Toplumda kadın ve erkek cinsiyet rollerinin farklı bakış açısıyla ele alınışını, Biyolojik Kuram erkek ve kadının farklı biyolojik özelliklerine dayalı olarak açıklamaktadır. Kadının biyolojik olarak anne rolünü üstlenmesi yanında toplumun beklentileriyle birlikte ailenin ihtiyaçlarını karşılamaya doğru devam etmektedir (Sert Ağır, 2017). Bulgulara göre aile içinde, kadınlar geleneksel yapının dışına çıkılması gerektiği görüşünde iken erkekler açısından halen annenin çocukla ilgili görev ve sorumluluklarının daha ağır bastığı söylenebilir. Bu bulgular da yine toplumdaki aileye ilişkin geleneksel bakış açısının yoğunlukta olduğu şeklinde yorumlanabilir.

Çalışmada, yaşı 30 ve daha küçük olan bireylerin, yaşı daha büyük olanlara göre çocuk bakımı hususunda annenin ön planla olması ve anne-çocuk bağlantısının güçlü olması gerektiği görüşünde oldukları belirlenmiştir. Değerlere ilişkin görüşlerde yaş önemli bir ölçüt olabilir ve zamana bağlı olarak kuşaklar arası değişim görülebilir. Abay ve Demir (2014) çalışmalarında, özellikle otorite, saygı ve dindarlık gibi soyut kavramları tanımlanmada kuşaklararası farkın daha belirgin olduğunu belirlemişlerdir. Toplumsal değişme süreciyle beraber, gençlerde daha fazla bilinçlenme yaşanmaya başlamıştır. Buna bağlı olarak, çalışmada 30 yaşın altındaki bireylerin anne ve çocuk ilişkisinin önemini daha fazla benimsedikleri söylenebilir.

Çalışmada, lisans mezunlarının ilköğretim mezunlarına göre ailenin saadeti için şiddeti meşru görme durumlarının daha yüksek düzeyde olduğu belirlenmiştir. Türkiye Nüfus Sağlık Araştırması (2008) sonucunda, kadının aile içi şiddet görmesinin haklı gerekçeleri olabileceği görüşü lise düzeyinde ve daha fazla eğitime sahip kadınlarda \%5,3 iken ilkokul mezunlarında \%46,9 bulunmuştur (Akt.: Başar ve Demirci, 2015). Öğrenim durumuna ilişkin, bu bulgunun çalışma bulgularından farklı olduğu görülmektedir. Şiddetle ilgili etmenlerden biri eğitimdir ve özellikle ilkokul düzeyinde öğrenime sahip kadınların daha fazla şiddete maruz kaldıkları belirlenmiştir (Ediz ve Altan, 2017). Lisans mezunu bireylerin geleneksel rolleri benimsedikleri ve bu durumun şiddeti kabul düzeyi üzerinde etkili olduğu söylenebilir. Bedir ve arkadaşları (2017) şiddet gören kadınlarla yaptıkları çalışmada, katılımcıların \%53,9'unun şiddet algısının şiddet tanımıyla uyumlu olmadığını, öğrenim düzeyi arttıkça şiddet algısının doğru olma durumunun da arttığını belirlemişlerdir. Bu çalışmada, şiddetin tanımına yönelik algının doğru olup olmadığı belirlenmemiş olup katılımcıların şiddetin tanımıyla ilgili algılarının doğru olmadığı düşünülebilir.

Çalışmada, öğretmen veya doktor gibi profesyonel bir mesleğe sahip olanların çalışmayan veya memur olanlara göre daha fazla evlilik kurumuna önem verdikleri ve kadını konvansiyonel bir bakış açısıyla 
değerlendirdikleri belirlenmiştir. Evlenen bireyleri farklı bir sosyal statüye dahil eden evlilik ve evlilik kurumuna bakış, farklı değişkenlerden etkilenebilmektedir. Evlilik kurumuna bakış ve kadının aile içindeki geleneksel rollerinde, yaşanılan yerin etkili olduğu gözlemlenmiştir (Aktepe ve Tahiroğlu, 2016). Evli bireyler, evliliğin devamını sağlama konusunda daha olumlu görüşlere sahip olabilirler. Özellikle, evli olan kadınların ailedeki birlikteliğin devamını sağlamak isteğiyle uzlaşmayı ön planda tutmak istemektedirler (Fındıkoğlu, 1991). Aile kurumu, evlilikle başlamaktadır. Kültürel bir yapının ürünü olan evlilik ve aile kurumu, gündelik hayatın bir parçasıdır ve değer aktarımında aracılık etmektedir. Ediz ve Altan (2017), çalışmalarında en fazla şiddet gören kadınların herhangi bir işte çalışmadıklarını ve bir gelirlerinin olmadığını belirlemişlerdir. Profesyonel meslek sahibi olmanın öğrenim durumuyla yakından ilişkili olduğu düşünüldüğünde, çalışmanın öğrenim durumuyla aile içi şiddete bakış açısına ilişkin sonuçlarının birbirini desteklediği, öğrenim durumu yüksek ve profesyonel bir mesleğe sahip katılımcıların geleneksel aile yapısını daha fazla kabul ettikleri söylenebilir.

Çalışmada, üç ve daha fazla çocuğu olan yetişkinlerin tek çocuğu olanlara göre cinsellikle ilgili konularda daha fazla serbestlikten yana oldukları, iki çocuğa sahip olanların çocuk bakımı konusunda annenin ön planda olması ve anne-çocuk arasında güçlü bir bağ olması gerektiği görüşünde oldukları belirlenmiştir. Çocuk sahibi olup olmama durumu ve çocuk sayısı, eşler arasındaki iletişim ve uyumu etkilemektedir. Çocuk sahibi olan bireylerin, çocukla ilgili sorumluluklardan kaynaklanan sorunları olabilir. Karadağ (2015) yaptı̆̆ çalışmada, çocuğu olan çiftlerin evlilikteki uyumlarının düşük olduğunu belirlemiştir. Yapılan bazı araştırmalarda, cinsellikle ilgili çatışmaların zaman içinde arttığını göstermektedir. Çocuk sayısı fazla olan bireylerin evlilik sürelerinin de fazla olduğu düşünüldüğünde, bu bilginin çalışma bulgularını desteklediği söylenebilir. Günümüzde ailenin geçimini sağlama sorumluluğunu kadın da üstlenmiştir. Bu nedenle, çocuk bakımı sorumluluğunu erkekler de almaya başlamışlardır. Buna rağmen, kadınlar ev ve çocuklarla ilgili daha fazla sorumluluk üstlenmektedirler (Eşsizoğlu vd., 2012).

Yine çalışmada, hiç çocuğu olmayanların ise geniş aileye ve akraba ilişkilerine daha az önem verdikleri belirlenmiştir. Geleneksel aile değerlerinde, akrabalık ilişkilerinin daha ön planda olduğu düşünülebilir. Ekşi ve arkadaşları (2015), Almanya'da yaşayan Türklerle yaptıkları çalışmalarında küçük yaşlarda evlenmiş olma ve çocuk sayısının fazlalığı gibi özelliklerin geleneksel aile değerlerinin devam ettirilmesinde etkili olduğu sonucuna ulaşmışlardır. Ailenin kültürel bir değer olduğunu düşünmekle çocuk sayısının fazla olması paralel olarak ilerlemektedir. Ailenin çocuk sahibi olup olmaması veya çocuk sayıs1, akrabalık ilişkilerinin yününü de etkileyebilmektedir (Şeker, 2015). Gölçük (2007), çalışmasında bireylerin akrabalarıyla görüşme nedenlerinin \%4,1 çocuğuna bakıyor olması olduğunu, $\% 71,5$ en sık anne-babayla görüşüldüğünü ve diğer akrabalarla görüşme oranlarının oldukça düşük olduğunu belirlemiştir. $\mathrm{Bu}$ çalışmayla ilişkilendirildiğinde, özellikle çocuk sahibi olmayanların akrabalarla ilişkilere daha az önem vermeleri hızlı kentleşmeyle ve çekirdek aileyle dönüşümün artmasıyla açıklanabilir.

Sonuç olarak; geçmişten günümüze aile içi ilişkiler incelendiğinde, toplumsal değişime uyum sürecinin etkisinden söz edilebilir. Aile değerlerinde bireysel, ailesel, çevresel ve toplumsal faktörler etkili olmaktadır. Dünyada yaşanan değişimlerle birlikte, ailelerin ve dolayısıyla aile değerlerinin de değişime uğraması kaçınılmazdır. Fakat önemli olan, toplumda kabul gören toplumsal, dini, ahlaki, kültürel vb. açıdan ele alınan değerlerin aile kültürü içerisinde sürdürülmesi ve bir sonraki nesile aktarımının sağlanmasıdır.

Bilgilendirme/Acknowledgement: Bu çalışma, 18-19 Mayıs 2019 tarihinde İstanbul'da düzenlenen " $2^{\text {nd }}$ International Congresses on New Horizons in Education and Social Sciences (ICES - 2019)" da sözlü bildiri olarak sunulmuştur. 


\section{KAYNAKÇA}

Abay, A. ve Demir, S. (2014). Belli parametrelere göre kuşaklararası sosyal değişme (aile değerleri üzerine bir karşılaştırma). Akademik Incelemeler Dergisi (Journal of Academic Inquiries), 9(1), 125-151.

Aktepe, V. ve Tahiroğlu, M. (2016). Değerler eğitimi yaklaşımlarl ve etkinlik örnekleri. The Journal of Academic Social Science Studies, 4, 361-384.

Aydın, M. Z. (2017). Eğitim sistemimizde değerler eğitiminin önemi. 15 Temmuz 2019 tarihinde http://yenidunyadergisi.com/egitim-sistemimizde-degerler-egitiminin-onemi// adresinden erişildi.

Aydın, M. Z. ve Akyol Gürler, Ş. (2012). Okulda değerler eğitimi yöntemler etkinlikler kaynaklar. Ankara: Nobel.

Başar, F. ve Demirci, N. (2015). Toplumsal cinsiyet eşitsizliği ve şiddet. KASHED, 2(1), 41-52.

Bedir, N., Ekerbiçer, H. Ç., İnci, M. B., Köse, E., ... ve Kılıç, Z. (2017). Sakarya'da yaşayan bir grup kadının şiddet algı durumları ve bunu etkileyen faktörler. Sakarya Tip Dergisi, 7(4), 188-196.

Dermott, E. (2014). Intimate Fatherhood: A Sociological Analysis. UK: Routledge.

Ediz, A. ve Altan, Ş. (2017). Türkiye'de kadına yönelik şiddet üzerine bir alan araştırması. TBB Dergisi, (Özel Sayı), 397-409.

Ekşi, H., Erkilet, A., Otrar, M., Durmuş, A., Erdoğan, A., Kılınç, C., Kızılkan, N. ve Gökçek, Y. Z. (2010). Medya Profesyonellerinin ve Medyanın Aile Algısı. Ankara: ASAGEM.

Ekşi, H., Demirci, İ., Yıldız, C. ve Ekşi, F. (2015) Almanya'da yaşayan Türk göçmenlerinin aile değerleri. Değerler Ĕgitimi Dergisi, 13(29), 41-82.

Ergene, T. (1999). Effectiveness of test anxiety reduction programs: A meta-analysis review. Yayınlanmamış doktora tezi, Ohio University, Ohio.

Eşsizoğlu, A., Yenilmez, Ç., Güleç, G. ve Yazıcıoğlu, Y. (2012). Aile yapısı ve ilişkileri (Ed. Ç. Yenilmez). Aile ile ilgili temel kavramlar. Eskişehir: Anadolu Üniversitesi, 2-20.

Giddens, A. (2000). Sosyoloji. (çev. Hüseyin Özel, Cemal Güzel). Ankara: Ayraç.

Gölçük, M. (2007). Kentleşme sürecinde akrabalı ve komşuluk kültürü (Afyonkarahisar örneği). Yayımlanmamış yüksek lisans tezi, Afyon Kocatepe Üniversitesi Sosyal Bilimler Enstitüsü, Afyonkarahisar.

Karadağ Ş. (2015). Evlilik uyumu ilişskisinde aile içi iletiş̧imin rolü: Konya örneği. Yayımlanmamış doktora tezi, Selçuk Üniversitesi Sosyal Bilimler Enstitüsü, Konya.

Karadaş, N. (2012). Televizyon reklamlarında aileye ilişkin değerlerin temsili. Selçuk Iletişsim, 7(3), 7889.

Kızıler, H. ve Canikli, İ. (2015). Değerler eğitimi. Karabük: Deneme.

Kızmaz, Z. (2006). Şiddetin soyo-kültürel kaynakları üzerine sosyolojik bir yaklaşım. Fırat Üniversitesi Sosyal Bilimler Dergisi, 16(2), 247-267.

Koç, R. ve Akdoğan, H. (2018). Çocuklarda değer aktarımının önemi. The Journal of Academic Social Science Studies-JASSS, 65, 1-16.

Martorella, P. H. (2001). Teaching social studies in middle and secondary schools. New Jersey: Merril Prentice Hall.

Özer, M. ve Aktaş, B. Ç. (2019). Değerler eğitimi devamlılığı: Okul öncesi eğitim programından hayat bilgisi öğretim programına. İlköğretim Online, 18(1), 389-405. 
Özyürek, A., Çetin, A. ve Erakman, S. (2016). Üniversite öğrencilerinin aile değerlerine bakışı. Eğitimde Gelecek Arayışları Dünden Bugüne Türkiye'de Beceri, Ahlak ve Değerler Eğitimi Uluslararası Sempozyumu Kitabı,1, 417-440, 16-18 Nisan 2015/Bartın. Ankara: Atatürk Kültür, Dil ve Tarih Yüksek Kurumu Atatürk Araştırma Merkezi.

Quisumbing, L. R. ve de Leo, J. (Eds.) (2010). Learning to do: values for learning and working together in a globalized world. Report prepared by The Asia Pasific Network for International Education and Values Educaation in Partnership with UNESCO-UNVEOK International Centre for Technical and Vocational Education and Training Sourcebook. Germany: Bonn. 21 Temmuz 2019 tarihinde https://files.eric.ed.gov/fulltext/ED495380.pdf adresinden erişildi.

Sert Ağır, M. (2017). Anne-çocuk ilişkisinin kalitesinde annelerin ruh sağlığının ve psikolojik iyi olma halinin önemi: "Pilot çalışma: Küçük grup çalışması". Istanbul Sosyal Bilimler Dergisi, 17, 30-51.

Sönmez, V. ve Alacapınar, F. (2011). Bilimsel araştırma yöntemleri. Ankara: Anı.

Şeker, C. (2015). Yahudilikte evlilik ve cinsellik anlayışı/ahlakı. Erzurum: İlted.

Törüner, E.K. ve Büyükgönenç, L. (2012). Çocuk sağllğı temel hemşirelik yaklaşımları. Amasya: Göktuğ.

Türk Dil Kurumu (2011). Güncel Türkçe sözlük. Ankara: TDK Yayınları. 21 Temmuz 2019 tarihinde http://sozluk.gov.tr/ adresinden erişildi.

$\begin{array}{llllll}\text { Türkiye } & \text { Cumhuriyeti } & \text { Anayasası. (2019). } & 15 & \text { Temmuz } 2019 & \text { tarihinde }\end{array}$ https://www.icisleri.gov.tr/illeridaresi/turkiye-cumhuriyeti-anayasasi adresinden erişildi.

2709 no'lu 18/10/1982 tarihli kanun. 9/11/1982 Sayılı Resmi Gazete. 5(22), 3.

Zajda, J. (2014). Vaules education. In D. Phillips (ed.). Encyclopedia of Educational Theory and Philosophy. USA: Thousand Oaks, Sage. 